\title{
4 \\ The Self-Fulfilling Prophecy of a Registration Drive
}

Question: Can dance hostesses [wunü] who have graduated from junior high school or above register as unemployed intellectuals?

Answer: Dance hostesses and others who meet the official criteria can register as unemployed intellectuals.

- STAFF MANUAL OF THE SHANGHAI MUNICIPAL COMMISSION FOR HANDLING UNEMPLOYED INTELLECTUALS, 1951

[She] became a Guomindang member during the Anti-Japanese War; husband teaches in a factory-run school. Not that sophisticated; saw great progress during training. Poor awareness in the past; now can criticize [political and ideological offenses and injustices]. Likes to help others and to laugh; not serious enough; has the gift of gab; straightforward.

-AN OFFICIAL ENTRY ON CHEN TAOZHEN, 32, A STATE-LABELED

UNEMPLOYED INTELLECTUAL LOOKING FOR WORK, 1952

On December 1, 1951, slightly over two years after the PRC's founding, the Shanghai government began a registration process for persons officially referred to as "unemployed intellectuals" (shiye zhishifenzi). Similar registrations occurred in Beijing and other major urban areas. The main purpose of the registrations was to locate educated but jobless people, ascertain their background and experience, and return as many of them as possible to work, especially in sectors and regions where replenishment or expansion of the labor force was needed. Because of two decades of war and revolution, unemployment had become a national problem. From the perspective of the new political leadership, the harnessing of otherwise unused knowledge and skills was not only vital to socialist development but also necessary for tackling joblessness. The registration drive in Shanghai lasted for fourteen months and overlapped with various highly charged national campaigns, including the Campaign to Suppress Counterrevolutionaries, the Resist-America-Aid-Korea 
Campaign, the Three Anti and the Five Anti Campaign, and Thought Reform of Intellectuals. These other campaigns involved mass parades, public denunciations, incarcerations, executions, and other poignant dramas. ${ }^{1}$ With the registration drive, there is apparently little to attract those scholarly lenses that routinely focus on the excesses of coercion or politicization of ordinary life by the Mao regime. In those rare instances when it is spotlighted, the registration is depicted as little more than a public welfare event, or else the official interpretation is presented. ${ }^{2}$

With this chapter, we begin our investigation of the mutual constitution of the intellectual and Chinese Communism in postrevolutionary China. In Shanghai, the registration of unemployed intellectuals turned out to be a key exercise across state and society that served to objectify the intellectual. To conduct the registration, the municipal government set up commissions and offices; printed instructions, regulations, and manuals; and devised application forms, assessment protocols, and identification cards. The government posted announcements in newspapers and other places and involved professional, trade, and other organizations. It arranged meetings, training sessions, and visits to local neighborhoods to educate CCP cadres and residents about unemployed intellectuals and official efforts to locate and assist these individuals. Eager to find paid work or help family members to do so, neighborhood residents sought information and studied eligibility criteria. Many gathered documents, filled out application forms, and prepared themselves for interviews. Cadres and residents thus learned how the state defined intellectuals in professional and academic terms, amid its complaints about the class character of these people and calls for them to learn from workers and peasants. Like the overlapping campaigns which advanced CCP control of government, industry, and other sectors, the registration drive helped the party extend its symbolic power and administrative capability into local neighborhoods. The drive furthered goals of the campaigns such as spreading the Marxian vision of Chinese society and the party's principles of social classification, recording and ascertaining the backgrounds of individuals, and mobilizing their participation in officially sponsored activities. Furthermore, the drive enabled the authorities to reach the unemployed, who otherwise had little incentive to observe state-mandated routines or procedures.

The boundaries of the category of intellectuals that emerged during the registration drive were no more clear or stable than those found in Yan'an a decade before, even though the CCP was much richer in resources for enforcing its system of social classification. Shanghai saw a proliferation and repeated replacement of rules and regulations governing registration eligibility, with contents that reflected varying official approaches to revolutionary justice, the allocation of opportunities, and the reduction of unemployment as much as changing official efforts to clarify the kinds of people to be considered unemployed intellectuals. Although the registration drive turned many unemployed people directly (as well as employed people indirectly) into locally recognizable "intellectuals," ambiguities regarding 
who the intellectuals were persisted. Meanwhile, some individuals used the drive for self-interested purposes, registering themselves or others who did not meet the criteria for recognition as unemployed intellectuals. In other words, in the lower reaches of the population of intellectuals formed under Chinese Communism, as in the upper echelons described in the last chapter, we encounter in sharp relief the political and social forces as well as individualized and institutionalized conduct that objectified some as intellectuals but not others who had similar backgrounds or even superior education. The category of intellectuals everywhere assumed a historical form that reflected the dynamics of Chinese Communism.

As unemployed intellectuals appeared en masse across Shanghai, official surveillance intensified in the local neighborhoods and the growing state sector. The city had been the major financial, industrial, and commercial center in China and home to political and official bodies sponsored by British, Japanese, and other foreign authorities and, not least, the Guomindang. Even without the citywide purges launched by the victorious CCP to rid government offices, colleges, and other sites of people confirmed or presumed to be staunch political enemies, many of the unemployed still had worked for other political regimes, foreign or domestic capital, or "vice" businesses eventually closed by the state such as nightclubs and cabarets. For the Shanghai authorities, among the unemployed intellectuals were many who had been involved in the political repression, economic exploitation, or moral corruption of the Chinese people. Clarifying the backgrounds of the intellectuals was necessary to forestall future problems of governance. Within the state-run establishments instructed to train or hire the intellectuals, the authorities used political and moral standards gleaned from official discourse to screen and select candidates. They investigated the chosen and monitored, documented, and categorized their behavior. The "petty-bourgeois" and "bourgeois" politics, habits, and dispositions of intellectuals described in official discourse were converted into visible realities and written records. The usable yet unreliable intellectual who had emerged in Yan'an not only migrated into the postrevolutionary workplace, but in many cases did so in the form of a figure detested by the local authorities.

To use Pierre Bourdieu's terminology, the intellectual appeared twice in homologous forms during the Shanghai registration of unemployed intellectuals, that is, both in the objective structures of the state and in the mental structures of ordinary people. The classification saturated various forms of official announcements, informed registration rules and activities, and led to specific mechanisms of domination within local neighborhoods and workplaces. Under these circumstances, government officials, registration staff, enterprise administrators, and neighborhood residents began to consider themselves and/or others as intellectuals, or a specific type of political subjects based on the Marxian understanding promoted by the state. What bridged the classification across two kinds of structure was the symbolic power and administrative capability of the Mao regime, both of which the registration drive helped to strengthen, notwithstanding that the concept of 
intellectuals remained unstable because of central adjustments of registration criteria and variations of local understanding. Before moving on, it is vital to highlight the dynamics of displacement and employment in Shanghai and nearby areas from the late 1940 s to the early 1950s, which critically influenced the kinds of people who would claim to be unemployed intellectuals and therefore how the authorities reacted.

\section{DYNAMICS OF PRESELECTION}

Like other Chinese cities, Shanghai, with a population of approximately 5 million people, saw high unemployment while the civil war (1946-1950) raged between the CCP and the Guomindang. ${ }^{3}$ The CCP takeover of the city, which began in late May 1949, was followed by capital flight, foreign economic sanctions, Guomindang air raids, a Guomindang naval blockade, and other challenges that intensified the problem of joblessness. ${ }^{4}$ From March to May 1950, an additional 150,000 workers were laid off. ${ }^{5}$ The municipal government followed central instructions and registered and organized assistance for the unemployed. ${ }^{6}$ The recovering city was hit with economic decline again in the spring of 1952 because of the state-sponsored Five Anti Campaign, which attacked tax evasion, bribery, cheating on government contracts, and other economic wrongdoing in the commercial and industrial sectors. Many firms responded to the campaign by terminating, suspending, or cutting back operations, which led to a "wave of sackings" of white-collar and blue-collar workers and manual laborers.7 Over 414,0oo people reportedly signed up for unemployment assistance during 1952, and more than 300,000 remained on the registry two years later. ${ }^{8}$ These figures do not include people who had some but inadequate work, homemakers and sojourners looking for work, and others who stayed away from all forms of official registration for one reason or another. In short, Shanghai's unemployment rate hovered above 10 and sometimes 20 percent during the early 1950 s. $^{9}$

Critical to our analysis are the forms of displacement that preselected those who would come forward during Shanghai's registration of unemployed intellectuals. In August 1948, the CCP implemented its personnel policy in northeast China when state agencies (including government departments, the military, the police, and the judiciary) and state-run establishments (such as schools, newspapers, and radio stations) were seized from the Guomindang. When the Red Army entered Beijing and Tianjin in January 1949, CCP cadres were directed to "shake up" existing state agencies, except those overseeing public utilities and public health. The cadres were asked to dismiss "reactionary elements, notoriously objectionable people, and unusable incompetents," assess the background and performance of the rest of the staff, and retain only the minority who were vital to everyday operation. Anyone who was rendered redundant but did not fall into any of those rebuked categories of people would be reassigned to another 
post or sent home with an allowance and an order to wait for official assignment. Across state-run establishments, the cadres were instructed to keep the workforce intact and dismiss only the most notorious, the steadfastly reactionary, and the incompetent employees. During the spring and summer of 1949, however, massive layoffs unanticipated by the Mao leadership occurred during the takeovers of Shanghai, Nanjing, and Hangzhou. Almost 27,00o people were cut from state agencies and state-run establishments. ${ }^{10}$ In Shanghai, more than 6,00o people were laid off; another 800 were dismissed; a few thousand more were instructed to wait for assignment or to return to their native places, or simply resigned. ${ }^{11}$ For example, almost 280 people, or 20 percent of the workforce, were removed from the public secondary school system. ${ }^{12}$ The layoffs triggered "mass social unrest" and compelled a tactical retreat from the leadership. In September 1949, takeover cadres were directed to remove from office only "the minority of war criminals and special agents [of enemy regimes] and notoriously objectionable elements," and to even rehire some of the people who had been laid off. ${ }^{13}$

In practice, former officials and administrators and others who were most offensive to the CCP authorities were ousted from state agencies and state-run establishments during the Shanghai takeover. Among those removed were leaders of Guomindang organizations and staunch supporters of the fleeing regime; former political, military, and intelligence officers; and people who had reportedly committed serious acts of wrongdoing such as graft or embezzlement or violent crimes against CCP members or supporters. The removal of Wang Guocai, the head of discipline and instruction at Yangshupu Secondary School in the summer of 1949, is illustrative. Undercover CCP agents had studied this Guomindang member and discovered that he had been a political instructor at the Luoyang campus of the Central Army Officer Academy (Zhongyang lujun junguan xuexiao). They determined that he was "obviously reactionary" in his political thinking and behavior. Wang reportedly had gotten his post at the secondary school, not because of his educational credentials or pedagogical skills, but through his connection with and willingness to serve the school principal, an alleged Guomindang special agent who had already left for Taiwan. Wang was said to have been a Guomindang mouthpiece throughout the civil war and, especially, in front of his students. ${ }^{14}$ Some of those removed from state agencies or state-run establishments would be arrested and even executed during the Campaign to Suppress Counterrevolutionaries (1950-1952); others would find work on their own or leave the city. The bulk would see the official registration of unemployed intellectuals as an opportunity to return to full-time employment.

In Shanghai, business closures pushed large numbers of office workers with different levels of knowledge and skills into the ranks of the unemployed. Between January and May 1950, 1,400, or more than 10 percent, of factories and 6,000, or 6 percent, of shops (shangdian) were closed. Although many of these establishments reopened in response to the surging demand created by China's involvement in the 
Korean War (1950-1953), bumper crops nearby, and state economic intervention, a total of 1,800 factories and 7,800 shops applied for closure in $1950 .{ }^{15}$ During the same period, more than 90 private banks and money houses (qianzhuang) were closed, or almost 60 percent of such establishments, because of the severe restrictions that the municipal government placed on financial exchange. ${ }^{16}$ Likewise, between August 1949 and December 1950, almost 600 of 1,600 import-export companies went out of business because of state regulation or other reasons. ${ }^{17}$ Private newspapers, news agencies, radio stations, publishing houses, and schools were forced to shut down or reorganize their operation to comply with new regulations. ${ }^{18}$ For example, almost 40 private schools ceased operation during the first year of CCP rule. ${ }^{19}$ Hotels, jewelry stores, dance halls, gambling venues, and other places that catered to a business clientele or encouraged consumerism also saw rapid declines due to official regulation. The Five Anti Campaign furthered closures of small and medium-sized enterprises. ${ }^{20}$ By May 1952, "urban unemployment was again high and confidence in the prospects for urban employment growth again shattered," ${ }^{21}$ prompting the municipal government, already a main consumer of industrial products, to increase loans and orders to local factories and organize mergers and other economic activities to arrest job losses. ${ }^{22}$

Two other forms of displacement increased the number of educated people among the unemployed in Shanghai. First, land reform began in the suburbs in July 1950 and was relatively peaceful until the Korean War intensified within months. Besides public denunciations and confiscation of land, animals, crops, and other forms of property, landlords faced investigation, arrest, and summary execution. Meanwhile, the Campaign to Suppress Counterrevolutionaries, which led to false accusations and reckless executions, spread across rural areas. ${ }^{23}$ Fengxian County, for example, located to the south of the city, saw 30 landlords sentenced to death and 129 given jail sentences. ${ }^{24}$ We do not know how many landlords or their family members fled to Shanghai. But the threat of punishment likely pushed some of these people to seek refuge there, where anonymity and therefore personal safety was still possible. Some of these newcomers had attended traditional tutor schools (sishu), modern-style schools, and even colleges. ${ }^{25}$ Second, closures and reductions of operation of various kinds of establishments within the city from the late 1940 s to the early 1950 s created tremendous pressure on household incomes, and drove homemakers who had received formal education to enter or return to the job market.

The way in which the CCP offered jobs and opportunities after seizing Shanghai depressed the average educational level of those who would register as unemployed intellectuals, especially among young men and women. To support its takeover of China, the party was determined to tap the "source of energy and enthusiasm" among secondary school and college students and recent graduates. This undertaking reflected the party's now-entrenched cult of youth. In practice, the Mao regime established many courses and centers to train young people for 
official service. ${ }^{26}$ Soon after the takeover of Shanghai had started, the East China Military and Political University (Huadong junzheng daxue) run by the People's Liberation Army (PLA) (previously the Red Army) sought to enroll at its Suzhou and Nanjing campuses 30,00o people aged between 18 and 28 with at least a junior high education. ${ }^{27}$ The PLA also wanted 3,000 "intellectual youths" from Shanghai, individuals between 18 and 30 years of age with that same education, to join the Southward-bound Service Corps and assist in propaganda, mobilization, and other tasks vital to the takeover of other cities or regions. ${ }^{28}$ Many other opportunities for intellectual youths to join the PLA followed, with age restrictions varying across recruiting organizations. For example, the garrison near Shanghai planned to train 950 men and 50 women who had graduated from high school to become "cultural cadres." ${ }^{29}$ Another unit needed 300 people to serve as "cultural and art workers." ${ }^{\circ}$ The Ninth Regiment had 1,200 openings in communication, art, and other capacities. ${ }^{31}$

Other careers in government were available to educated young people. For example, the East China People's Revolutionary University (Huadong renmin geming daxue) enrolled thousands with the aim of training them to assist the CCP takeovers occurring elsewhere. ${ }^{32}$ The East China branch of the Central Tax Administration Institute (Zhongyang shuiwu xuexiao) needed 500 people to learn to become "finance and tax cadres." ${ }^{33}$ And the Shanghai Cadre Institute (Shanghai ganbu xuexiao) wanted to train 1,00o people for various positions in the central government. ${ }^{34}$ There were opportunities for older educated adults. The positions, however, were often limited to those who had college education and professional experience and were willing to relocate. For example, representatives of the People's Government of Northeast China (Dongbei renmin zhengfu) were in Shanghai as early as September 1949 to recruit professors in various fields of science and technology as well as experts (zhuanjia) in similar areas and in law, politics, medicine, accounting, and so on. ${ }^{35}$ The Central Ministry of Heavy Industry announced a few months later a plan to hire factory management and technical personnel with university or technical college educations. ${ }^{36}$ The Dongbei government had almost 5,000 additional openings for various kinds of faculty, experts, and technical personnel. ${ }^{37}$

In sum, even though war and revolution had forced students in Shanghai to enter the labor market prematurely and increased the unemployment of recent graduates, many of these people did not need to use the subsequent official registration of unemployed intellectuals to return to work. Likewise, the knowledgeable but jobless had other channels to find work. The registration drive was destined to encounter large numbers of ordinary office workers, former Guomindang members and government officials, especially those whom the CCP had dismissed on political, moral, or even criminal grounds, and others who, for one reason or another, had not been able to take advantage of state-sponsored training or other opportunities. 


\section{STATE AND SOCIETY SEARCH FOR INTELLECTUALS}

In January 1951, the State Council of the PRC issued a "Supplementary Instruction on the Handling of Unemployed Intellectuals" that directed regional governments to return such people to work "to the fullest extent possible."38 The "instruction" followed months of assistance provided by the state to displaced office workers and technical personnel, unemployed graduates, and other educated people in the form of job placement or living subsidies, sometimes together with mandatory political reeducation. Reflecting its Marxian view of China's class structure, the state had been referring to these persons as unemployed intellectuals to distinguish them from unemployed workers (shiye gongren), whom it classified as part of the proletariat. Large numbers of such workers existed, and large shares of resources had been allocated to tackle their joblessness. ${ }^{39}$ With that instruction noted above, the state adopted the goal of registering unemployed intellectuals systematically, educating them at people's revolutionary universities and other venues, and placing them in the educational, industrial, and other sectors. The instruction included a statement of individual eligibility designed to help the local authorities to identify unemployed intellectuals. Heretofore a principal classification of people under Chinese Communism, the intellectual acquired a concrete administrative definition. "The range of people to be handled as unemployed intellectuals is as follows: (1) those who have at least graduated from senior high school or have an equivalent education, but have lost their jobs or have been unable to find work since leaving school; and (2) those who have considerable academic knowledge and prestige in the local area and are willing to serve the people, but cannot take up hard work or support themselves due to old age or poor health" (emphasis added). To undermine political enemies and lawbreakers, the State Council declared that "the minority of intellectuals" who had "degenerated into special agents [of other political regimes] or vicious thugs $(e b a)$ " or had committed serious criminal acts were not eligible for assistance. ${ }^{40}$ From the state's perspective, these intellectuals had apparently morphed into counterrevolutionaries or class enemies, or were no longer usable.

In Shanghai, the Shanghai Municipal Commission for Handling Unemployed Intellectuals (Shanghaishi chuli shiye zhishifenzi weiyuanhui) (SCHUI) was formed in October 1951. The commission was composed of officials from six municipal bureaus (education, personnel, civil affairs, labor, culture, and news and publications) and representatives from the General Office of the municipal government and the Shanghai branches of the Women's Federation, the Education Union, and the Communist Youth League. District (qu) branches of the commission were established to involve officials from corresponding district bureaus and representatives from an even broader array of organizations sponsored or sanctioned by the state, including political associations such as the China Democratic League (Zhongguo minzhu tongmeng) and the China Association for Promoting Democracy (Zhongguo minzhu cujinhui). The SCHUI formulated policies, 
procedures, and regulations for registering unemployed intellectuals, prepared applications forms and identification cards, and wrote press releases for newspapers. It organized classes to teach the district staff how to run the registration office, use bulletin boards, public assemblies, and other channels to publicize the registration drive, and handle applications. Manuals explaining official terminology, individual eligibility, standards of documentation, and other registration matters were printed and distributed. ${ }^{41} \mathrm{~A}$ total of ten registration offices were set up across urban and suburban Shanghai. ${ }^{42}$

The Shanghai authorities used junior (instead of senior) high school graduation or its equivalent level of education as the minimum academic qualification for registering as unemployed intellectuals. ${ }^{43}$ The change had apparently come from the State Council, as its subsequent instructions and decisions consistently defined unemployed intellectuals according to the relaxed criteria, which in effect increased manifold the number of people classifiable as intellectuals across China. ${ }^{44}$ There were probably three reasons behind the change. First, jobless people with high school diplomas were too few to justify an official registration campaign. Second, the Mao regime had deemed less educated persons to be intellectuals during its Yan'an years. Third, many schoolteachers, accountants, and others who fit into the Marxian concept of intellectuals of the state were not high school graduates. Included in the SCHUI staff manual were additional regulations and statements about eligibility, which show that the state continued to grapple with how to use the intellectual as a classification in administrative matters. For example, peddlers, pedicab drivers, and dance hostesses who had the required education could register as unemployed intellectuals, but not instructors from traditional tutor schools, because these individuals "lacked knowledge of modern culture and science." 45 Others were disqualified on political grounds, for example, denounced landlords hiding in Shanghai, expellees of state-owned enterprises, and college students who had refused official assignments. The SCHUI also wanted those discovered to be counterrevolutionaries or criminals during the registration drive to be handed over to the Public Security Bureau for further investigation and punishment. ${ }^{46}$

Research has stressed the CCP's imposition of a Marxian system of social classification on state and society during the early 1950s. The Shanghai registration of unemployed intellectuals enabled the party to extend this system into urban neighborhoods. Applicants had to put down, many for the first time, their class background according to the official double markers of "family status" (jiating chengfen) (e.g., poor peasant, petty bourgeoisie, capitalist) and "individual origin" (benren chushen) (e.g., student, office worker, industrial worker). Other requirements captured growing state surveillance that seized upon particular aspects of social life as objects of analysis. Applicants were instructed to describe their involvement in political organizations (zhengzhi qingkuang) and the backgrounds of close friends and relatives (shehui guanxi). Everyone had to submit an autobiographical narrative (zizhuan) of his or her "individual experience, changes in 
political thinking, understanding of the PRC government, and personal strengths and weaknesses." 47 As we shall see, the collection of these materials helped the local authorities not only to pin down each applicant's own particularity as a class subject, as Foucault might have said, but also to describe the general traits of the applicants as well as compare between any two of them based on the official analytical framework..$^{48}$

The SCHUI drew into the search for unemployed intellectuals many of the city's political, professional, trade, and other associations. The commission was expecting that some applicants had lost their academic diplomas, professional certificates, or letters of appointment because of war and displacement. It had thus asked prominent associations for assistance and trained their representatives in assessing and certifying educational achievements and employment histories. ${ }^{49}$ Numerous cases of missing documents were reported shortly after the registration drive had started, so much so that the commission augmented the list of certifying associations to roughly 300 . These associations included, for example, the Shanghai branches of the China Art Workers Association, the China Pharmacology Association, and the Sino-Soviet Friendship Association; the Shanghai Peasants Association and the Shanghai Homemakers Federation; and the district branches of various labor unions. Applicants without valid papers were instructed to approach an association related to their own occupation. The association was required to assign to each case two of its members, who would use their knowledge and familiarity with the applicant to evaluate that applicant's asserted qualifications, experience, and, if appropriate, class background, political involvement, and other matters that deserved attention. The association would then furnish a written report to SCHUI as to whether the applicant was an unemployed intellectual (see figure 3 )..$^{\circ}$

In Shanghai, the search for unemployed intellectuals intensified further after their registration was integrated into the Unified Unemployment Registration (shiye renyuan tongyi dengji) in October 1952. A national event, the unified registration sought to address the rising urban unemployment that resulted from the Five Anti Campaign. The registration was also designed to enable local governments to ascertain, among other things, the backgrounds of the unemployed, a population quite challenging for the state to reach, let alone control. The Shanghai authorities had noted that some who could sign up as unemployed intellectuals had not done so for reasons such as fear of relocation or arrest. ${ }^{51}$ Within every district, neighborhood unemployment registration committees (lilong shiye renyuan dengji weiyuanhui) were formed to publicize the registration drive and to document former officials and police officers as well as workers, homemakers, youths, and others who were jobless. Each committee normally contained seven to thirteen members who were residents of the neighborhood. The committees were supervised by the district's labor and employment commission, the members of which were drawn from various government offices. ${ }^{52}$ For example, in the 


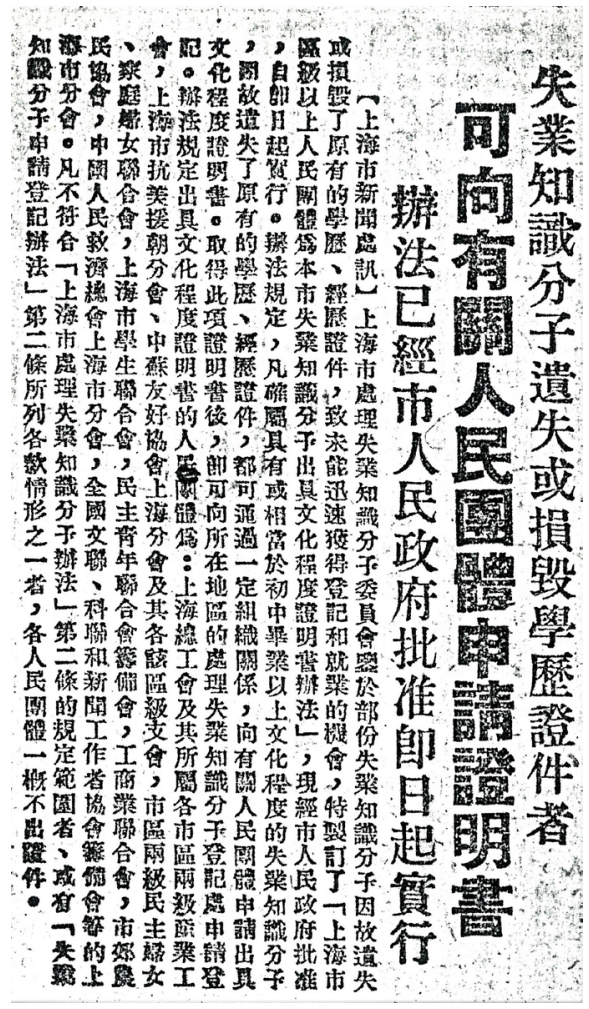

FIGURE 3. An announcement of the certifying role of associations in Wenhui Daily, January 8, 1952.

industrial district of Yulin, the population of which exceeded 230,000, the commission trained more than 1,800 unemployed workers, homemakers, and others to staff the neighborhood committees. These persons took classes on registration procedures and requirements. They learned criteria for categorizing people as unemployed intellectuals. They practiced alongside the authorities and performed tasks such as promoting the registration through bulletin-board messages, visiting families to explain policies and eligibility, and verifying documents and checking submitted applications. ${ }^{53}$

The unified registration in Shanghai, which lasted until January 1953, involved rule and regulation changes that affected, once again, how state and society understood the category of intellectuals. Politically based barriers to registration were lifted for members of the following disfavored groups: former Guomindang military officers and state officials; expellees from the military, government offices, and state-owned establishments; former Christian clergymen, Buddhist monks, 
fortune-tellers, and "religious and superstitious practitioners" of other kinds. So long as they satisfied the educational and unemployment requirements, such people could register as unemployed intellectuals. If the changes helped the state locate such personnel, place them where they could be monitored, and alleviate unemployment, it also served to absorb these people squarely into the population of intellectuals. Rule changes adopted for other reasons had classification and career impact, too. In a reversal, the authorities stipulated that those who had completed junior high school but had been making ends meet in a blue-collar or unskilled position for an extended period were ineligible to register as unemployed intellectuals. A homemaker with such education was no longer automatically considered an unemployed intellectual; unless her family was in dire poverty, her application for assistance would be "put on record," or handled after unemployed men with comparable qualifications had been helped. By contrast, displaced workers who had sought education in part-time schools and achieved the equivalent of junior high school graduation could choose to register as unemployed workers or unemployed intellectuals. ${ }^{54}$

A procedure of collective appraisal (pingyi) of unemployment status was adopted by the Shanghai authorities. As the next section will show, during the registration drive organized by the SCHUI, the authorities had good reasons to doubt the truthfulness of the applicants and the propriety of the registration staff. Collective appraisal was inserted to assist local governments with obtaining accurate information about the unemployed and in deciding case by case whether to list applicants on the placement registry, recommend them for state relief, act on their job request at a later time, or even deliver them for prosecution for discovered wrongdoing. Each neighborhood registration committee was required to form an appraisal team of about twelve people including district officials, registration staff, and some of the unemployed, and to invite local residents to appraisal sessions. The procedure thus fostered further public learning of the official schema of classes, including use of the intellectual classification.

What happened in Baxian Lane in Songshan district, which the Shanghai Municipal Commission of Labor and Employment cited as exemplary in conducting the registration drive, is illuminating. Officials from the commission organized multiple meetings to encourage members of the local residents' committee, women's representatives in the neighborhood, homemakers, the unemployed, and others to attend the appraisals. The local registration committee had already conducted pilot research and established appraisal procedures. The latter included discussion by the committee members of information provided by the unemployed; appearance of the unemployed before the committee to explain their background and experience; and feedback and questions from attending residents. The committee even asked the unemployed to evaluate one another's statuses. ${ }^{55}$ In short, the appraisals served as neighborhood forums in which officials and residents alike grappled with the class identity of each unemployed person with guidance from 
TABLE 1 Number of Wenhui Daily Articles with Specific Terms for Educated Persons, 1938-1957

\begin{tabular}{lcccc}
\hline & 1938 & 1946 & 1952 & 1957 \\
\hline Zhishifenzi (intellectuals) & 27 & 53 & 798 & 1,511 \\
Xuezhe (scholars) & 210 & 285 & 141 & 317 \\
Wenren (literati) & 93 & 113 & 26 & 80 \\
Wenhua ren (cultural personnel) & 25 & 113 & 12 & 9 \\
Dushu ren (men of letters) & 9 & 25 & 9 & 19 \\
\hline
\end{tabular}

SOURCE: Electronic database of Wenhui Daily at Shanghai Municipal Library.

${ }^{*}$ The figures include both zhishifenzi and zhi4shifenzi. The second one was dropped by the newspaper after the 1949 takeover.

the state. The exercise led all of the participants to consider their own class identities and those of their friends and relatives, if they had not already done so.

In Shanghai, these registrations played a unique role in turning the intellectual into a primary classification of people. For more than a year, every district was involved in studying the concept and locating unemployed intellectuals. Table 1 illustrates this development from a linguistic perspective. Wenhui Daily (Wenhui bao) was founded in Shanghai in 1938 and quickly became a major newspaper and channel for political and intellectual debate. Before 1949, the term zhishifenzi was used significantly less than other terms denoting educated people (which, unlike zhishifenzi, often signaled the basis of their knowledge). After 1949, CCP control of the media produced a surge in the use of zhishifenzi, as the party considered the other categories of people as subsets of intellectuals. The registrations and Thought Reform of Intellectuals overlapped in 1952 and pushed the use of the term to new heights, while it also circulated in abundance in radio, cinema, magazines, and public meetings-right when "intellectuals" were locatable in every neighborhood.

\section{A SELF-FULFILLING PROPHECY}

Between the two registration drives, the Shanghai authorities signed up 40,000 unemployed intellectuals. ${ }^{56}$ Table 2 indicates the self-reported ages and educational attainments of 34,100 people who registered during the first eleven months of the events. Half of the registrants merely satisfied the official minimum educational requirements. The two youngest cohorts contained the smallest proportion of college-educated members for reasons discussed above. Overall, only 12 percent had college education. Because educated homemakers could register as unemployed intellectuals during the SCHUI registration, women constituted a moderate majority ( 57 percent). In terms of professional knowledge, the largest proportion (35 percent) did not report any specific skills; 23 percent mentioned 
TABLE 2 Educational Attainments of “Unemployed Intellectuals" by Age (with Percentage), 1952

\begin{tabular}{lccccrr}
\hline & $18-25$ & $26-35$ & $36-45$ & $46-60$ & Above 6o & Total \\
\hline Junior high & 8,008 & 6,398 & 2,129 & 637 & 32 & 17,204 \\
& $(62.5)$ & $(45.3)$ & $(41.0)$ & $(35.2)$ & $(18.2)$ & $(50.4)$ \\
Senior high & 4,235 & 5,823 & 2,096 & 588 & 51 & 12,793 \\
& $(33.1)$ & $(41.2)$ & $(40.3)$ & $(32.5)$ & $(29.0)$ & $(37.5)$ \\
College & 568 & 1,898 & 953 & 536 & 65 & 4,020 \\
& $(4.4)$ & $(13.4)$ & $(18.3)$ & $(29.6)$ & $(36.9)$ & $(11.8)$ \\
Other & 3 & 16 & 20 & 50 & 28 & 117 \\
& $(0.0)$ & $(0.1)$ & $(0.4)$ & $(2.7)$ & $(15.9)$ & $(0.3)$ \\
Total & 12,814 & 14,135 & 5,198 & 1,811 & 176 & 34,134 \\
& $(100.0)$ & $(100.0)$ & $(100.0)$ & $(100.0)$ & $(100.0)$ & $(100.0)$ \\
\hline
\end{tabular}

SOURCE: SMA B1-1-1121, 206.

NOTES: "College" refers to at least two years of postsecondary vocational training. "Other" refers to the possession of professional expertise or recognized knowledge and local reputation but not formal academic credentials.

experience in finance or economics, but mainly as bookkeepers or elementary learners of accounting; 19 percent were former schoolteachers or had worked in education, arts, literature, or the news media; another 7 percent were former clerical workers. ${ }^{57}$

Having expected to find a substantial number of knowledgeable and skillful people-for example, physicians, surveyors, factory supervisors, and mechanical engineers-the registration authorities were disappointed. "Many of the registrants are of low cultural level; only a small number have high academic or professional achievements ... Although our methods of classification and figures suggest that we have a number of technical personnel, rarely do these people have genuine expertise or robust learning. The majority have acquired their skills and knowledge from part-time school, have been jobless because of chronic illness, or have not worked before. ${ }^{58}$ In hindsight, this outcome was inevitable. The state had set junior high school graduation or its equivalent educations as the minimum educational requirement for anyone to register as an unemployed intellectual. Official programs of training and recruitment had absorbed many with knowledge and skills or college educations into various occupations. Seeing many relatively young people among the registrants, the authorities nonetheless toed the line of the officially promoted cult of youth and indicated that most of the registrants would contribute to China's socialist development after receiving training from the state.

More disturbing to the registration authorities was their no-less-inescapable discovery of the disagreeable political backgrounds and orientations of the registrants. Six months into its registration drive, the SCHUI issued an installment 
of what would become a consistently scathing official assessment of unemployed intellectuals during the 1950s. There were, the report stated, "many sons and younger brothers of landlords and rich peasants, members of reactionary parties and youth corps, former judicial personnel, bureaucrats, public school teachers, and former military officers and so on, and the family members of these people." These kinds of registrants generally had "very poor understanding [of the revolution led by the CCP], very backward thinking [about class exploitation inside or outside China], and very insufficient appreciation of the serve-the-people viewpoint [of Chairman Mao]." The commission practically restated the outcomes of the recent purges conducted by the party in government offices, the judiciaries, and other sites in or near Shanghai. But the SCHUI downplayed the institutional sources of the unemployment by highlighting the joblessness as a symptom of the inferior class-based character of the registrants. The latter allegedly exhibited a "strong desire to lead a life of pleasure and enjoyment and hence an aversion to taking jobs outside Shanghai." 59 As we shall see, although jobs were available elsewhere, it was not easy for registrants to obtain any of these positions, even if they were ready to leave their families behind or move with them to the new locations of employment. To the authorities, however, the inability of unemployed intellectuals to get work outside the city was yet another indication that they were refusing to confront their "petty-bourgeois" or "bourgeois" habits and dispositions acquired from families, schools, and workplaces in a city known for its commercialism and consumerism.

The SCHUI's unease about the registrants also reflected disruptions of the registration drive during early 1952, when the Three Anti Campaign, which attacked malfeasance in government, and the Five Anti Campaign were in their early phases. District cadres who worked in the registration offices were reassigned to assist in the investigative and punitive campaigns for roughly two months, when thousands of people signed up as unemployed intellectuals. The SCHUI discovered afterward that "the mental condition of the office staff had slipped into a state of extreme disorder." Worrying about their own prospects and the well-being of friends and relatives, staff members became listless and confused as well as divided and disgruntled. Consequently, the registration drive was tainted by irresponsible and illicit behavior. Zhabei district was an undistinguished working-class area. The registration office there was cited by the commission as an egregious example. Someone who knew little about the registration drive had assumed leadership. The staff "did whatever they felt like doing." They came to work late and left early together, played chess in the office, and used field trips and investigations as excuses to go home or to cinemas or billiard halls. Conventional and emerging social divisions surfaced and produced a fractured workplace at other sites. Staff members from government offices and from state-sponsored associations quarreled with one another, and so did male and female cadres, young and old personnel, and Communist Youth Leaguers and the rest of the staff. In Fenglai district, 
office staff reportedly dreaded coming to work and hoped the registration would end immediately. Elsewhere, some of the operating funds were stolen, staff members suddenly quit, and even the office sign was not hung properly. ${ }^{60}$

Registration work was predictably compromised. The SCHUI had expected registration office staff to assist in verifying information provided by applicants. Ideally, staff members would visit the establishments (e.g., colleges and companies) and locations (such as previous home addresses) mentioned by the applicants to gather evidence and determine in an "objective" and "systematic" manner whether they had been truthful. Lacking training and supervision, the commission noted, even those who had conducted such investigations performed poorly. Some had asked questions of little value and submitted "crude and careless" reports. In Yimiao district, for example, the registration office failed to catch someone who had lied about a friendship with a CCP member to increase his own chances of placement, and another person who had covered up involvement in the intelligence service of another political regime. In some cases, female relatives of "counterrevolutionaries" had passed as "general representatives of women" of the neighborhood and were recommended for job assignment. In other cases, individuals known locally as fraudsters or bullies were logged as activists who supported CCP policies and personnel. Some staff members, moreover, followed their own belief in "benevolence and gentleness" and compiled grossly simplistic reports about applicants. ${ }^{61}$

The SCHUI uncovered that registration staff had exploited the management vacuum created by the Three Anti and Five Anti Campaigns to help friends, relatives, and others. Some staff members used the official seal fraudulently to approve otherwise unqualified applications and even recommended ineligible candidates to recruiting establishments. For example, a cadre in Laozha district had taken money from applicants. He was prepared to sign up ineligible people as unemployed intellectuals and process their placements. In Xincheng district, a staff member insisted on sending a colleague's sister-in-law to a teacher-training program organized by Shanghai Normal College, even though she did not meet the publicized political requirements. Another staff member had fallen in love with an applicant and sought to use his position to find her a position. ${ }^{62}$ The illicit behavior reflected, to a good extent, the challenges that some unemployed persons confronted in acquiring a livelihood, as the state increasingly controlled the labor market and administered opportunities based on principles of class struggle. Other kinds of improper behavior noted by the commission-for example, the registration offices repeatedly sanctioned counterfeit diplomas and letters of employment-were mainly an outcome of the large volume of applications processed by the staff and the lack of training and supervision provided by the SCHUI authorities. ${ }^{63}$ From the latter's perspective, however, the registration of unemployed intellectuals was tainted twice: by the selfish, class-based conduct of the applicants and by that of the registration staff. 
By May 1953, only 31 percent, or 10,500, of the 34,100 unemployed intellectuals represented in Table 2 had found jobs through state assistance. Another 2,300 found work themselves, and 253 saw their registration disqualified after official investigation. A higher proportion of male registrants (34 percent) than of female registrants (29 percent) were assisted in paid positions or traineeships. Educational achievement mattered. Among those who had attended college, 39 percent acquired a position, compared with 36 and 25 percent of the senior high and junior high school graduates. Almost 30 percent of the placements were outside Shanghai. Most of those who received appointment (39 percent) were hired for general office work or as some kind of trainee, 24 percent for finance or accounting work, and another 22 percent as cultural workers or schoolteachers. Only a small number were placed in highly technical fields such as engineering, medicine, or factory management. ${ }^{64}$ The relatively low percentage of registrants who received an official assignment did not indicate a lack of interest from recruiting establishments, which were mainly government departments and state-owned enterprises expanding rapidly under CCP rule. Within the first twelve months of the registration of unemployed intellectuals, almost 140 establishments contacted the SCHUI. ${ }^{65}$ Some submitted plans to hire hundreds or more of these people. For example, the East China Department of Education had 3,000 vacancies. ${ }^{66}$ The low rates of success reflected a mismatch between what many of these establishments wanted-technicians and technical personnel (jishu renyuan)—and the registrants' knowledge and skills. ${ }^{67}$

Equally important, the poor placement rates were results of political vigilance on the part of the recruiting establishments, or their efforts to avoid acquiring individuals portrayed or implicated as political undesirables by the state, such as former Guomindang personnel, former landlords, and people who had received official punishment. The general approach of the establishments, the SCHUI observed, was "rather be understaffed than indiscriminately taking on new employees" (ningque wulan) and preferential treatment of "the youngest possible candidates." 68 The collective outcome was reflected in the rates of placement of the cohorts represented in Table 2. Thirty-five percent of the youngest cohort of registrants, or those with the least work experience, received assignments, compared to $31,26,13$, and 1 percent of registrants in the successive cohorts. It is true that young people tended to be single or childless and hence open to relocation. Positions outside Shanghai, while plentiful, usually paid less (because the state calculated salaries on the basis of regional living standards), and therefore were not attractive to many who had a family to support in the city. However, the rates of placement suggest that discrimination against older registrants was in play. For the recruiting establishments, the backgrounds reported by young registrants in their applications and autobiographical narratives, however misleading, were easily verifiable compared with the long lists of appointments, connections, and activities 
or, worse, the lack of such information furnished by older candidates. The political vigilance of the establishments reflected and reinforced the cult of youth spreading within the state sector.

What happened to Yu Jielin's job search, which the SCHUI cited as not uncommon, is instructive. Yu was a struggling 36-year-old with two years of senior high education and a family of three to feed. Before the registration of unemployed intellectuals began, he had received two months of training from the Shanghai branch of the People's Insurance Company of China but was not given a position there. To make ends meet, he performed various kinds of lowly physical work. After successfully registering as an unemployed intellectual, Yu was recommended to the Shanghai Medical Equipment Manufacturing Company and passed its written and physical exams. Still, the company did not offer him anything. Quite puzzled, SCHUI officials contacted the company and learned that he was rejected because of his "complicated political background." According to the registration information provided by $\mathrm{Yu}$, he was no more than a former low-level supporter of Guomindang rule who had served as a village chief and attended an officially sponsored political training course. ${ }^{69}$ Other establishments, the commission noted, took caution to a similar extreme when considering unemployed intellectuals for positions. The East China Bureau of Mining Management declined to accept any candidates unless the Shanghai Public Security Bureau investigated their backgrounds and guaranteed that the candidates had not been members of Guomindang organizations. Some establishments wanted to know that the candidates were "politically reliable" or had a "clean history", and refused to accept qualified police statements such as "up to now no political problem has been found with this candidate." According to SCHUI, the Provincial Government of Rehe evaluated 134 candidates for 100 positions in finance and economics and hired only 12 (a 9 percent rate of acceptance). The East China Bureau of Geology was apparently more risk-tolerant. Management looked at 611 candidates for 500 trainee vacancies and took 167 (a 27 percent rate of acceptance). ${ }^{70}$

Once detected by those seeking to register as unemployed intellectuals, the recruiting establishments' vigilance compounded these persons' tendency to withhold information from the authorities. Some of them inverted a well-known official slogan to express what they believed would give them the best chance of rejoining the workforce. They stated that the state practiced "ruthlessness for those who confess [their wrongful pasts], and leniency for those who cover up [such background]" (tanbai congyan yinman congkuan), instead of the other way around as promised. The SCHUI indicated that there were registrants who had chosen not to reveal some of their connections, activities, or appointments until after starting the new position. ${ }^{11}$ To be sure, recruiting governments and enterprises understood that among unemployed factory and other manual workers were people who had been dishonest about their backgrounds and activities. However, since the state 
had no plan to place such workers in professional or administrative positions in large numbers, such establishments did not have to worry about their impact on everyday operation.

In brief, a self-fulfilling prophecy emerged. The Mao regime wanted to exploit the knowledge and skills of "unemployed intellectuals" for purposes of socialist development, even though it considered these persons politically unreliable. The way in which the emerging state conducted appointments and dismissals as well as the registration drives predetermined the kinds of people who came forward as unemployed intellectuals and asked for assistance. Few of them possessed professional training or experience. Many had worked for Guomindang or had other background disapproved by the state. Furthermore, neither the state nor recruiting establishments could quickly verify personal information provided by those who claimed to be unemployed intellectuals. In the end, the Mao regime obtained what it had anticipated-a pool of intellectuals who could fill various kinds of position but who it feared would wreak havoc on socialist development.

\section{THE DEEPENING OF THE SURVEILLANCE STATE}

In April 1952, after five months of registering unemployed intellectuals, the SCHUI responded to lingering questions from higher authorities and recruiting establishments about the registrants' backgrounds. The commission's leaders gathered staff members from every district and explained to them a "mass-line" (qunzhong luxian) approach to investigation, borrowing the term from the famous method of revolution articulated by Mao during the Yan'an phase of Chinese Communism. The investigations would henceforth involve local branches of state-sponsored associations and local residents' committees; local officials, CCP activists, and homemakers; and the relatives, friends, neighbors, and former colleagues of the applicants. With each application, registration staff would approach the local associations and the local residents' committee to confirm claims about educational attainment, work experience, family background, and so on. Additional care would be needed for applicants whose "situations are relatively complicated," or with whom hints existed that they had worked for the Guomindang or other political regimes, served the exploiting classes beyond the role of an ordinary white-collar worker, or lied in their applications. Staff members were instructed to interview as many people as necessary in the local neighborhood, contact the applicant for further information, and visit or write to the mentioned workplaces to clarify what positions the applicant had held, the quality of performance, and the reasons for termination. Staff members were asked to hold "investigative group meetings" with people who knew the applicant well to obtain further information. If doubts persisted as to whether the person had committed serious crimes, assistance from the Public Security Bureau or the local police station would be warranted. The goal was to have everyone contacted "candidly disclose every piece 
of information" they had on the applicant. The staff could then assess the credibility of the informants and the evidence and therefore the true identity of the applicant. $^{72}$

This mass-line approach of the SCHUI to investigating unemployed intellectuals was fanciful thinking. The commission and its staff constituted but an extremely thin layer of the municipal bureaucracy, which was simultaneously managing other official campaigns across the city. The frontline registration personnel lacked opportunities to execute the ambitious investigation, not to mention appropriate training or support to accomplish the task. Nonetheless, the approach revealed that the official view of the intellectual as a usable but unreliable subject informed surveillance practice in urban society. The registration authorities feared that some unemployed intellectuals might be resentful of CCP rule or even plotting against it. At the very least, these intellectuals shared habits and dispositions harmful to socialist development. In the authorities' minds, who these persons were, what they believed, and what they had done thus had to be clarified. As we have seen, two of the investigative procedures mentioned by the commission were actually deployed during the subsequent Unified Unemployment Registration: extensive neighborhood participation and public discussion.

As official surveillance on the unemployed intensified across Shanghai, recruiting establishments that could neither wait for the SCHUI to complete its investigation nor exclude unemployed intellectuals from hiring plans took matters into their own hands. What happened at the New Education College of Shanghai (Shanghai xinjiaoyu xueyuan) offers a window on the tactics and strategies of such establishments, few of which had resources to pursue comprehensive personnel investigation during the early 1950s. The college was originally set up to train instructors in primary, secondary, vocational, and factory-run schools to become CCP activists. Due to the rapid expansion of the Shanghai school system, the college quickly switched to preparing displaced schoolteachers to return to work. A few months into the registration of unemployed intellectuals, the college's mission was extended to the training of such persons for school positions. During the summer of 1952, the college enrolled almost 3,000 unemployed intellectuals, of whom over two-thirds were women, in a six-week residential course. The training involved little instruction in pedagogical skills or academic subjects. The course was modeled after the ideological reeducation program that the CCP had developed in Yanan, which was then deployed widely across Shanghai as part of Thought Reform of Intellectuals. The trainees were required to learn about the policies of the Mao regime, its interpretation of politics, society, and history, and what it regarded as the correct approach to work. Most important for our purposes, mandatory "confessions" (tanbai) were an integral part of the training. ${ }^{73}$

The college authorities were most interested in learning the political backgrounds and activities of the unemployed intellectuals. The details obtained through confessions would not only reveal how each of these persons had 
approached the 1949 revolution, but also serve as the bases for determining job assignment and other kinds of action. The authorities apparently guided the trainees in a particular manner to elicit their cooperation.

Depending on the ideological state of the trainees, we repeatedly explained the official policy [of educating, reforming, winning over, and uniting with intellectuals] to dispel misgivings, and we patiently and sincerely taught and helped the trainees to attain self-awareness. We did not push or force them. We let them move from ordinary issues in their political life to past involvement in significant political activities, from their thinking to their participation in organizations and activities, from helping them to identify friends [of the revolution among people whom they know] to recognizing its enemies, from fragmented self-examinations [of ideological missteps and mistakes] to holistic confessions [of background and activities] as their awareness improved ... At every stage, we selected successful examples as guides, played instructional films, and showed what the trainees had accomplished with the confessions to educate the trainees themselves. Finally, we helped the trainees further to reveal their backgrounds in a lucid and concrete manner through their writing of autobiographical narratives and open discussions of the content of the narratives. ${ }^{74}$

From the confessions, the authorities identified 952 of the trainees (33 percent) as having "problems" in their backgrounds. Among the serious cases, which numbered above 200, 49 people had reportedly held leadership positions at the district or higher level of the Guomindang or other "reactionary" political organizations. Forty-eight were former special agents of Guomindang intelligence or para-intelligence agencies or had served the collaborationist regime in similar capacities during the Anti-Japanese War. Thirty-eight had occupied the post of section chief or higher offices in the Guomindang government. Seven had attained the rank of brigade commander or above in the Guomindang military. Ten were former landlords; 51 were "CCP renegades." A few were former drug traffickers and convicted criminals..$^{75}$ It is unclear how these results compared with what the trainees had stated when they registered as unemployed intellectuals. The state recognized that, in general, some thought reform participants exaggerated their past activities and wrongdoings because of pressures to conform to official expectations as well as to show cooperation and remorse in front of peers and superiors. ${ }^{76}$ One thing, however, is incontrovertible. The college expended material, symbolic, and intellectual resources to investigate every trainee in response to direct instructions, with the underlying belief that unemployed intellectuals were usable but unreliable.

Official surveillance at the college did not stop with the backgrounds, beliefs, and behavior of the trainees. The authorities monitored, evaluated, and documented the "ideological state" (sixiang qingkuang) of everyone and any changes therein, or what these men and women were prone to feel, think, and do as class subjects. ${ }^{77}$ The official discourse on intellectuals became the analytical foundation on which the trainees were apprehended. Instruction, conversations, symposiums, 
and other campus activities became occasions for observation, examination, and documentation; the speeches and comportments of the trainees and their interaction with the authorities and one another were sources of information. The authorities were especially interested in two things: first, the extent to which the trainees supported the socialist project, the official policy on intellectuals, and the state's plan to reeducate these people; and second, the trainees' effort to overcome their own self-centeredness, indiscipline, and other undesirable traits that they had allegedly acquired since childhood and in roles such as official, firm manager, and schoolteacher. Like the confessions, the assessments were used to determine appointments, or punishment if necessary.

When the training began, the college authorities reported that self-interest was a major reason behind the enrollments. Some trainees had no desire to work in a school, but needed a job. Some joined the class so they could show their families that they were making efforts at finding employment. Some women stated that having a regular income would free them from the bullying of in-laws. Diagnosed, too, was a lack of understanding of the training and its intentions, as manifested in allegations such as "training classes organized by the CCP are identical to concentration camps [jizhong ying]; labor reform is inevitable," and in rumors that "those who performed poorly will be sent to Subei [the northern part of Jiangsu Province] or northeast China to help open up remote areas and perform farm labor." The authorities documented cynicism toward ideological reeducation from expressions such as "individualism is part of human nature and can't be altered" and "bring on thought reform if that's what I need to get a job." ${ }^{8}$ As comments and conduct were entered into official records, every trainee became "a describable, analyzable object"79 or, in the authorities' eyes, a class subject with specific ideological, moral, and behavioral inclinations.

The next chapter explores, among other things, how postrevolutionary surveillance inside the workplace intensified the objectification of the intellectual with an "ever more subtle partitioning of individual behavior." ${ }^{80}$ Suffice it to mention here that the college authorities adopted a quasi-official system of notation, a set of recurring vocabulary based on the official discourse on intellectuals, to sum up their observations. The vocabulary facilitated not only concise communication of the trainees' attributes as class subjects and comparison between trainees, but also their evaluation in relation to the ideological, moral, and behavioral expectations of the state. Desirable attributes identified by the authorities included, among others, "sincere about learning" (xuexi renzhen) the material furnished by the state, "aspiring to make progress" (yaoqiu jinbu) to meet official standards, "upright in their ways" (zuofeng zhengpai), and "relatively honest" (jiao laoshi) given the corruptive commercial and moneymaking culture of Shanghai. Examples of negative attributes were "backward thinking" (sixiang luohou) on political, economic, and social issues; fear of hardship, challenges, and extra work ( $p a$ chiku); tendency toward being "rash and irritable" (xingqing jizao); and "rather strong 
petty-bourgeois proclivities" (xiao zichan jieji qingtiao jiaonong) in terms of speech, attire, and lifestyle. ${ }^{81}$

In the end, almost all of the 3,00o trainees were assigned to a position in a school. This does not mean that the college authorities were confident about their knowledge of these people or pleased with the latter's performance during the six weeks of ideological reeducation. The high placement rate reflected, instead, increasing demand for schoolteachers and other school personnel across Shanghai. ${ }^{82}$ In fact, the appointments were only for six months initially. The receiving campuses were expected to examine and further reeducate the appointees to determine whether they deserved permanent employment. In other words, state surveillance of the trainees migrated into their newfound workplaces. Roughly 60 trainees (2 percent) did not receive any assignment. One category of rejects included former Guomindang personnel who were uncooperative and others who had reportedly committed violent crimes or were suspected of having been sabotaging CCP rule. The Public Security Bureau was notified about these people; with its consent, however, they still could be considered for positions at schools. Members of a second category were not considered for any school position. These were mainly men and women who had signed up as unemployed intellectuals fraudulently or fugitives or criminals required to be processed by the court or the police. ${ }^{83}$

In their notable study of social classification, Bowker and Star suggest that if "a category did not exist contemporaneously, it should not be retroactively applied." ${ }_{4}$ The alternative, they argue, is to lose sight of dynamics related to how systems of classification emerged and evolved, or a unique window on politics, society, and history. On the eve of the 1949 revolution, ordinary Chinese had little reason to talk or think about "intellectuals," let alone consider whether they personally belonged to this social category. Not long after the revolution, embodied subjects referred to as intellectuals were locatable across China. The registration drive described above captures the impact of the Yan'an approach to the intellectual on its ontological transformation. The triumphant Mao regime wanted nationwide cooperation from usable but unreliable "intellectuals." Before long, the Shanghai government began to use its symbolic power and administrative capability to locate jobless intellectuals. Looking to improve their lives or those of their families, many evaluated whether they were intellectuals eligible for official assistance and nudged others to do the same. The web of texts, conversations, and interactions that spread across the city during the registration drive turned it into a collective learning exercise, one that involved the intellectual as a classification of people. When the drive ended, every neighborhood had a new category of people-intellectualsalbeit with the boundaries of this population remaining ambiguous.

At the same time, governance in Shanghai took on specific features because of the official view that some of the unemployed were usable but unreliable 
intellectuals. For one thing, the municipal government spread its tentacles deep into neighborhoods and performed propaganda, liaison, training, and other tasks that served to strengthen its presence. Second, the government deployed large amounts of resources on surveillance because of worries that some unemployed intellectuals were saboteurs, criminals, or others who would wreak havoc in the workplace. Third, the government expanded ideological reeducation as means to transform as many unemployed intellectuals as possible into assets of socialist development. In a nutshell, as the registration drive objectified otherwise perfectly ordinary people into intellectuals, official deployment of mass surveillance, ideological reeducation, and workplace management by party cadres intensified under Chinese Communism. 